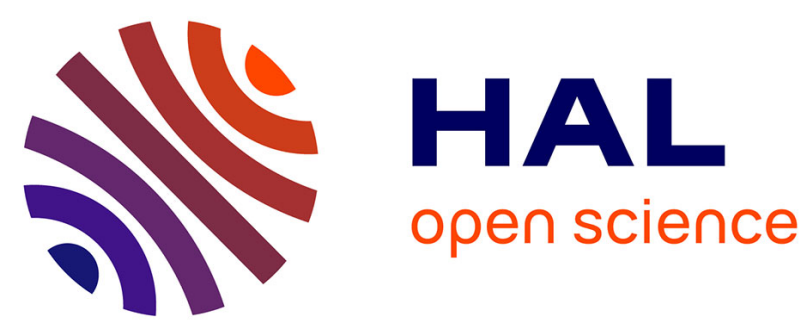

\title{
Prurigo pigmentosa induced by ketosis ("keto rash"): a demonstrative case and internet search results
}

Jérémie Delaleu, Etty Grynberg-Laloum, Philippe Moguelet, Pierre Hamann, Camille Francès, Annick Barbaud, Patricia Senet

\section{To cite this version:}

Jérémie Delaleu, Etty Grynberg-Laloum, Philippe Moguelet, Pierre Hamann, Camille Francès, et al.. Prurigo pigmentosa induced by ketosis ("keto rash"): a demonstrative case and internet search results. International Journal of Dermatology, 2020, 59 (7), pp.876-877. 10.1111/ijd.14873 . hal-03272022

\section{HAL Id: hal-03272022 \\ https://hal.sorbonne-universite.fr/hal-03272022}

Submitted on 28 Jun 2021

HAL is a multi-disciplinary open access archive for the deposit and dissemination of scientific research documents, whether they are published or not. The documents may come from teaching and research institutions in France or abroad, or from public or private research centers.
L'archive ouverte pluridisciplinaire HAL, est destinée au dépôt et à la diffusion de documents scientifiques de niveau recherche, publiés ou non, émanant des établissements d'enseignement et de recherche français ou étrangers, des laboratoires publics ou privés. 
1 Title: Prurigo pigmentosa induced by ketosis ("keto rash"): a demonstrative case and

2 Internet search results

3

4 Authors: Jérémie Delaleu ${ }^{1,2}$, Etty Grynberg-Laloum ${ }^{3}$, Philippe Moguelet ${ }^{2,4}$, Pierre Hamann ${ }^{1,2}$,

5 Camille Frances $^{1,2}$, Annick Barbaud ${ }^{1,2}$, Patricia Senet ${ }^{1,2}$

6

7 1: Department of Dermatology, APHP, Tenon Hospital, Paris, France

8 2: Sorbonne University, Paris, France

9 3: Dermatology Practice, Place Gambetta, Paris, France

4: Laboratory of Pathology, APHP, Tenon Hospital, Paris, France

11

12

13 14 15 16 17

Correspondence to: Jérémie Delaleu, MD

Dermatology Department

APHP, Saint Louis Hospital

1, avenue Claude Vellefaux

75010 Paris, France

Email: jeremie.delaleu@aphp.fr

Tel: +33666571544

\section{Conflict of interest: None}

\section{Running head: prurigo pigmentosa induced by ketosis}

Key words: prurigo pigmentosa, ketosis, keto diet

Word count: 592

References: 5

Figures: 1

Table: 0 
Prurigo pigmentosa (PP) is an inflammatory skin disorder characterized by the development of erythematous papules with a net-like distribution ${ }^{1}$. Although there is no clear cause for PP, several mechanical factors have been associated with the disorder, including ketosis which appears to induce the eruption of $\mathrm{PP}^{1,2}$. On the Internet, there is a skin condition popularly coined "keto rash" in blogs and forum discussions. Researching medical information is currently the third most common use of the Internet, and the first source for health information before consulting a physician ${ }^{3}$. Although websites may include useful information and cite current literature, in other instances health-related information may be misleading. Herein, we report a case of self-diagnosed PP in a young woman who followed a ketogenic diet for weight loss and we evaluate content available on the Internet for keto rash. A woman in her 20s was referred to our dermatology clinic for a pruritic skin rash that had been evolving for one month. Skin examination revealed scaly erythematous papules coalescing into plaques arranged in a reticulate pattern on the chest, the retro-auricular scalp, the neck and the nasolabial folds, along with pigmented macules on the lower back (Fig. 1). A skin biopsy on a pigmented macule demonstrated nonspecific lichenification with acanthosis, hyperorthokeratosis, keratinocytes apoptosis and lymphocytic perivascular infiltrate (Fig. 2). In the absence of a clear diagnosis, the patient was reassessed two weeks later. She then spontaneously reported that she had been following a ketogenic diet for 3 months to lose weight. Our patient herself suggested the diagnosis of keto rash. Reintroduction of carbohydrates into the diet associated with doxycycline regimen resulted in the total disappearance of the skin rash within two weeks with no relapse after a 10-month follow-up.

Our Google search using the term "keto rash" produced 1,580,000 results. Of the first 10 search results, 9 were websites attributed to self-proclaimed experts and promotional information and 1 was an educational resource. Most of the websites advised PP patients to wait and see (8/10), reintroduce carbohydrates (10/10), avoid "allergens" such as dairy, eggs, fish, shellfish, tree nuts or peanuts (6/10), take vitamin supplements (6/10), avoid various skin irritants, including heavy sweating (5/10), not use antibiotics, or only as a last resort (3/10).

The pathogenesis of PP is not well understood, but a strong association with ketosis arising with various etiologies has been reported. A ketogenic diet consists in reducing the carbohydrate content in the diet while increasing fat and protein intake. There is resurgence in the interest in this diet regimen because there are a growing number of reports of its beneficial effect in terms of weight control, cardiovascular disease, etc. ${ }^{4}$ With the increasing popularity of ketogenic diets, more frequent accounts of PP have emerged. In most cases, reintroduction of carbohydrates into the diet is sufficient to cure keto rash; if this treatment is insufficient, 

oral cycline antibiotics are usually the first-line therapy for $\mathrm{PP}^{5}$. Most of the results from our 70 Internet search on ketosis-induced PP were webpages whose accuracy may be uncertain. The 71 information and their recommendations (cited above) regarding PP are not evidence-based.

72 Due to easy, widespread access to health-related information on the Internet, patients may opt 73 to self-diagnose and therefore delay seeking professional care.

74 In conclusion, PP should be considered in patients on a ketogenic diet who have cutaneous 75 discredit any unfounded recommendations regarding ketosis-induced PP.
78

79

80

81

82

83

84

85

86

87

88

89

90

91

92

93

94

95

96

97

98

99

100

101

102 
Figure 1 Clinical presentation of prurigo pigmentosa. (a) Scaly erythematous papules arranged in a reticulate pattern on the chest. (b) Scaly erythematous and brown papules on the neck. (c) Pigmented macules arranged in a reticulate pattern on the lower back.

Figure 2: pathological presentation of prurigo pigmentosa with nonspecific lichenification with acanthosis, hyperorthokeratosis, rare keratinocytes apoptosis and lymphocytic perivascular infiltrate of superficial dermis (HES, Original magnification x250).

\section{$\underline{\text { Acknowledgements }}$}

Jérémie Delaleu had full access to all the data in the study and takes responsibility for the integrity of the data and the accuracy of the data analysis.

We have no conflicts of interest to declare.

The author(s) received no specific funding for the research, authorship, and/or publication of this article.

\section{$\underline{\text { References }}$}

1. Oh YJ, Lee M-H. Prurigo pigmentosa: a clinicopathologic study of 16 cases. $J$ Eur Acad Dermatol Venereol. 2012;26(9):1149-1153. doi:10.1111/j.14683083.2011.04263.x

2. Hartman M, Fuller B, Heaphy MR. Prurigo pigmentosa induced by ketosis: resolution through dietary modification. Cutis. 2019;103(3):E10-E13.

3. Prestin A, Vieux SN, Chou W-YS. Is Online Health Activity Alive and Well or Flatlining? Findings From 10 Years of the Health Information National Trends Survey. J Health Commun. 2015;20(7):790-798. doi:10.1080/10810730.2015.1018590

4. Paoli A, Rubini A, Volek JS, Grimaldi KA. Beyond weight loss: a review of the therapeutic uses of very-low-carbohydrate (ketogenic) diets. Eur J Clin Nutr. 2013;67(8):789-796. doi:10.1038/ejcn.2013.116

5. Böer A, Misago N, Wolter M, Kiryu H, Wang XD, Ackerman AB. Prurigo 
pigmentosa: a distinctive inflammatory disease of the skin. Am J Dermatopathol. 


\section{Figure 2:}

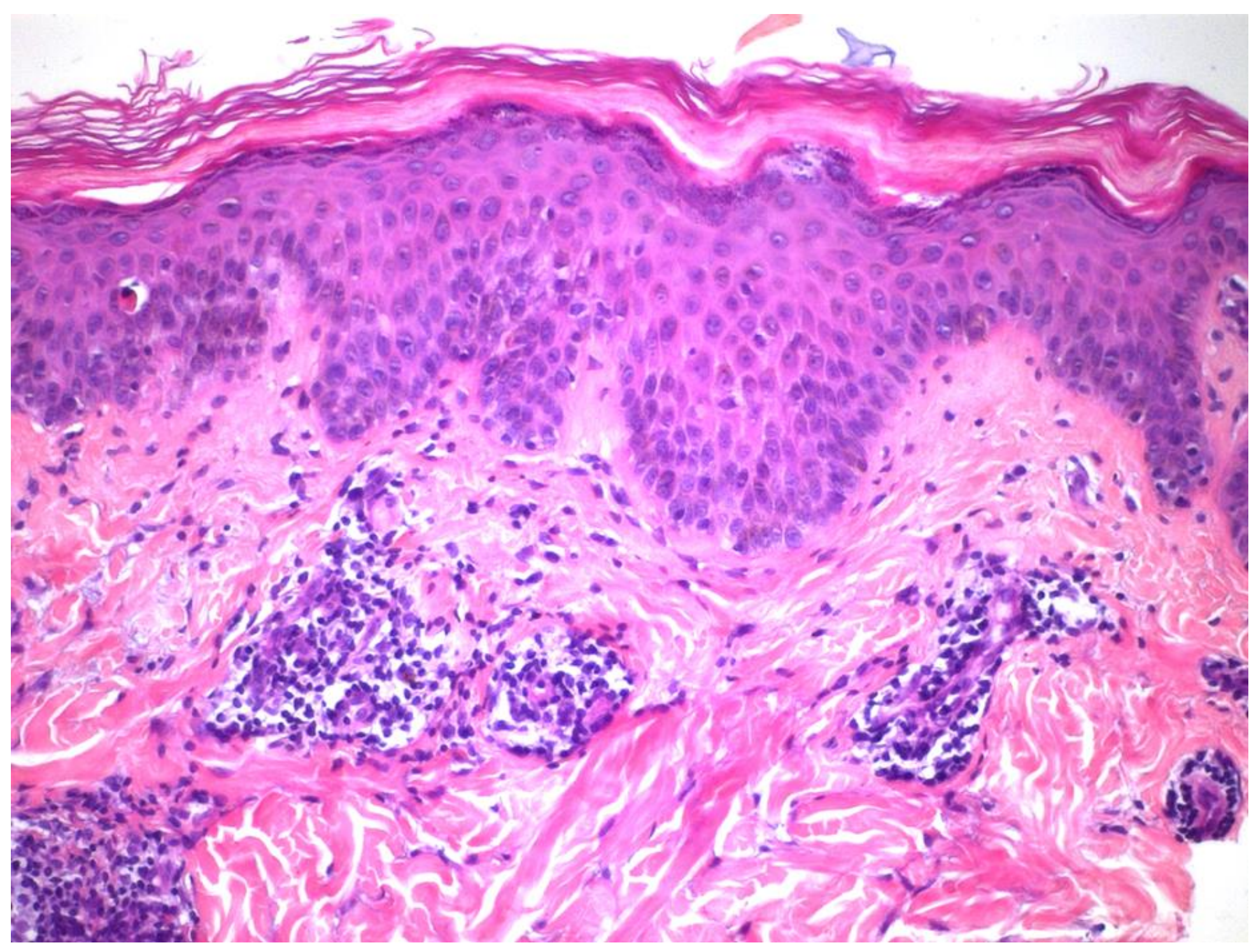


Figure 1:

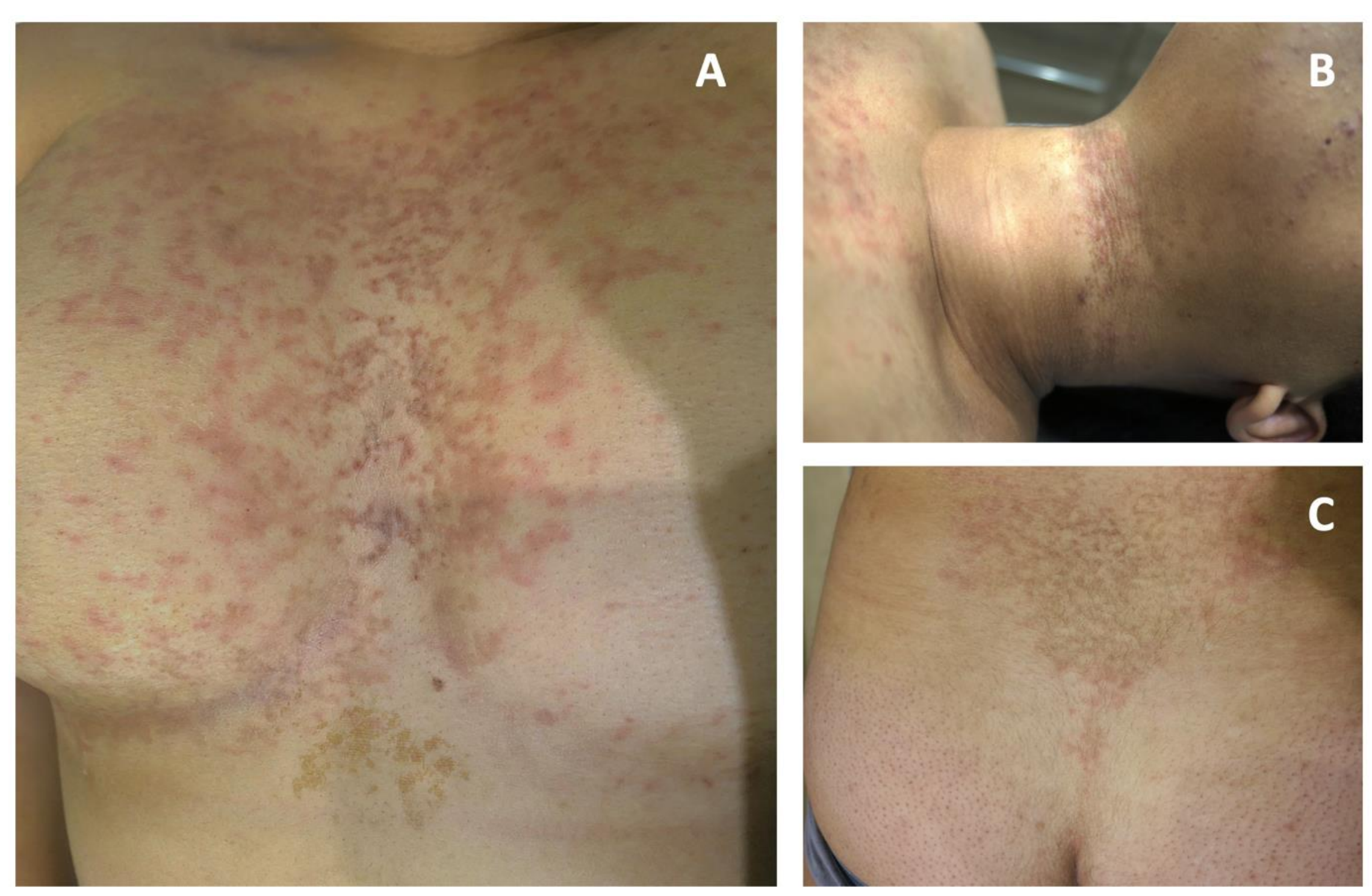

